\title{
Spatiotemporal density patterns of the pest predator Rhynchium haemorrhoidale (F.) along a land-use gradient in cacao agroforestry systems
}

\author{
Patrick Hoehn · Ingolf Steffan-Dewenter • \\ Damayanti Buchori · Teja Tscharntke
}

Received: 10 September 2007 / Accepted: 12 May 2008/Published online: 28 May 2008

(C) Springer Science+Business Media B.V. 2008

\begin{abstract}
Tropical insect species show year-round breeding activity due to favourable climatic conditions. However, most species also display seasonal reproductive peaks, but little is known about underlying causes of temporal density changes. We investigated population dynamics of the pest predator Rhynchium haemorrhoidale (F.) (Hymenoptera: Eumenidae) and its natural enemies in relation to season, climate and varying shade tree composition in cacao agroforestry systems in Central Sulawesi (Indonesia). Nesting of $R$. haemorrhoidale showed clear seasonality with highest densities in the wet season and lowest in the dry season, which was not related to changes in temperature. Wasp densities increased with land-use intensity, presumably because less-shaded areas offer more favourable climatic conditions and higher densities of the major prey, the cacao pest Agathodes
\end{abstract}

P. Hoehn $(\bowtie) \cdot T$. Tscharntke

Department of Agroecology, University of Göttingen,

Waldweg 26, 37073 Gottingen, Germany

e-mail: pathoehn@web.de

I. Steffan-Dewenter

Department of Animal Ecology I, Population Ecology, University of Bayreuth, Universitätsstrasse 30,

95440 Bayreuth, Germany

D. Buchori

Department of Pest and Plant Diseases, Faculty

of Agriculture IPB, Bogor Agricultural University,

Jl. Kamper Kampus, IPB Damarga, Bogor 16680,

Indonesia caliginosalis (Lepidoptera: Pyralidae). Pupal body size was higher in June than in November indicating increasing intraspecific competition due to high wasp densities and food shortage at the beginning of the wet season. Body size between habitat types was similar, thus season appeared to be more important than habitat in terms of food supply. High wasp densities in the wet season were associated with high diversity of the altogether seven parasitoid species. In conclusion, we found a pronounced seasonality of the wasp $R$. haemorrhoidale and a preference for little shaded agroforestry, which may be due to enhanced temperature and density of its prey. Our data indicate a high potential for biological control of a major cacao pest by management of nesting sites of $R$. haemorrhoidale.

Keywords Biological pest control . Ecosystem functioning $\cdot$ Host-parasitoid interactions - Intraspecific competition · Population dynamics · Resource availability

\section{Introduction}

Density and reproduction of tropical species show mostly distinct temporal peaks even though breeding seems to be possible all year round (Brown and Shine 2006). Hypothesized proximate causes for seasonality in tropical zones include abiotic factors (mainly rainfall), food limitation and top-down regulation by 
natural enemies (Harris and MacDonald 2007; Richards and Coley 2007; Richards and Windsor 2007). For some taxa, such as shrews or butterflies, it has been shown that they synchronize breeding with optimal climatic conditions (Kemp 2001; Nicolas et al. 2005).

Land use intensification in tropical agroecosystems reduces diversity of predators, thus reducing the potential ecosystem service of pest control (Perfecto et al. 2004; Philpott et al. 2007). Habitat quality has been discussed to be a crucial factor influencing species density due to microclimatic conditions or food resource availability in tropical and temperate regions (Schmidt et al. 2005; Lambert et al. 2006; Clough et al. 2007; Richards and Windsor 2007).

In this study we try to identify whether season or habitat more strongly influence the density of an important insect pest predator in agroforestry systems of different land-use intensity throughout a year. We asked whether food supply, climate, parasitism rate and entomopathogenic infection may be responsible for seasonal fluctuations in the density of a predator such as the eumenid wasp studied here. A major factor important to animal population dynamics is larval food supply. Due to changes in food resources between season and habitat, adult sex ratio, body size or mortality, as some crucial aspects of a predator's population dynamic, might also vary (King 1996; Strohm and Linsenmair 1997; Cleary and van Ginkel 2004; Boggs and Freeman 2005). Predators are strongly affected by fluctuations in prey density (Forsman and Lindell 1997; Salamolard et al. 2000; Norrdahl and Korpimaki 2002). Even though generalist predators exploit a broader array of resources than specialists, which may enhance stability of population densities, they may also face the problem of food limitation in space and time (Östman 2005). Decreased population density of an insect predator due to food limitation can be caused by intraspecific competition (Bommarco 1999). Besides larval food supply, climatic conditions are often an important factor, influencing the density of predacious wasp species. For some Hymenoptera, such as Vespidae, nesting activity is correlated with daily or seasonal changes in climate (Elisei et al. 2005; Ribeiro et al. 2006). Temperature dependent activity of the nest-building adults influences generation times and population density due to different provisioning times (Strohm and Linsenmair 1998). In temperate zones ontogenesis of insects is strongly related to seasonality, including specific hibernation stages as egg, larva, pupa or imago. Minor climatic fluctuations occur in tropical areas but might nevertheless influence reproduction and fitness (e.g. temperature and photoperiod). Parasitism rate is also well known to affect host population dynamics and may increase with increasing host density (e.g. Tscharntke 1992; Bischoff 2003; Teder and Tammaru 2003; Steffan-Dewenter and Schiele 2008). As parasitoids vary in space and time, they might be a crucial factor for host densities in different seasons and habitats (Zhou et al. 2001; Liu et al. 2007). Further mortality factors influencing density, may be often unknown, such as nematode or fungal infections due to increased humidity (Furlong and Pell 2001; Morton and Del Pino 2007). We investigated factors that may influence seasonality and spatial distribution of the solitary, predatory wasp Rhynchium haemorrhoidale (F.) (Eumenidae, Hymenoptera) along a land-use gradient of agroforestry systems in Sulawesi, Indonesia. The only prey species of $R$. haemorrhoidale was a cacao leaffeeding larvae of Agathodes caliginosalis (Snellen) (Pyralidae, Lepidoptera).

In the investigated agroforestry systems cacao plants are grown under different levels of shade tree diversity and densities as determinants of land-use intensity. Agroforestry systems become increasingly interesting for the conservation of global species richness and ecosystem services (Millennium Ecosystem Assessment 2005; Dietsch et al. 2007, Steffan-Dewenter et al. 2007). We were therefore interested in the question, whether agricultural habitats of different management intensities can maintain high densities of the predatory wasp species $R$. haemorrhoidale providing an important ecological function. We also examined, whether climatic conditions and food resource availability are more relevant for spatiotemporal patterns in the density, body size and sex ratios of $R$. haemorrhoidale. Furthermore, we evaluated the influence of parasitism rate and mortality due to unknown reasons (henceforth: non-parasitism mortality) on seasonality and habitat preferences of $R$. haemorrhoidale.

\section{Method}

Experimental site and design

Sampling was conducted on the western margin of the Lore Lindu National Park in Central Sulawesi, Indonesia, in the agroforestry systems surrounding the 
village of Toro (E $120^{\circ} 2^{\prime}, \mathrm{S} 1^{\circ} 30^{\prime}, 800-1,100 \mathrm{~m}$ above sea level). Agricultural landscapes at the margin of the tropical rainforests are dominated by cacao agroforestry and paddy fields. The landscape is heterogeneous resulting in alternating habitat types on a small scale.

We selected plots belonging to four habitat types ranging from natural forests to a gradient in land-use intensity of agroforestry systems. Each plot had a minimum core area of $30 \times 50 \mathrm{~m}$, where we placed the trap nests. The cacao agroforestry systems formed a gradient according to the composition of shade tree species and thereby canopy cover, with low management intensity agroforestry having natural forest trees as shade trees (high canopy cover), medium intensity systems having a diverse shade tree community planted by farmers (medium canopy cover) and high intensity plots with only a few planted shade tree species such as Gliricidia sepium (Jacq.) and Erythrina subumbrans (Hassk.) (low canopy cover). The different habitat types were situated close together but randomly mixed (see UTM data in Table 1). Four replicates were chosen for each habitat type.

Canopy cover was measured with a spherical densiometer (Model-C, Robert E. Lemmon, Forest Densiometers, 5733 SE Cornell Dr., Bartlesville, OK

Table 1 Canopy cover and location according to the Universal Transverse Mercator (UTM) system of each replicate per habitat type

\begin{tabular}{llll}
\hline Habitat/Replicate & $\begin{array}{l}\text { Canopy } \\
\text { cover in } \%\end{array}$ & $\begin{array}{l}\text { UTM } \\
\text { easting }\end{array}$ & $\begin{array}{l}\text { UTM } \\
\text { northing }\end{array}$ \\
\hline Primary forest 1 & 96.8 & 171,125 & $9,832,974$ \\
Primary forest 2 & 97.0 & 168,961 & $9,835,116$ \\
Primary forest 3 & 93.7 & 171,204 & $9,832,688$ \\
Primary forest 4 & 95.0 & 171,759 & $9,834,927$ \\
Dense shade agrof 1 & 69.6 & 169,333 & $9,833,896$ \\
Dense shade agrof 2 & 61.6 & 169,489 & $9,834,158$ \\
Dense shade agrof 3 & 82.3 & 170,737 & $9,833,172$ \\
Dense shade agrof 4 & 76.5 & 169,828 & $9,834,447$ \\
Medium shade agrof 1 & 76.0 & 170,450 & $9,832,604$ \\
Medium shade agrof 2 & 66.2 & 170,637 & $9,833,602$ \\
Medium shade agrof 3 & 57.0 & 169,937 & $9,833,662$ \\
Medium shade agrof 4 & 46.3 & 169,911 & $9,834,876$ \\
Low shade agrof 1 & 81.6 & 170,125 & $9,832,058$ \\
Low shade agrof 2 & 51.3 & 170,485 & $9,834,798$ \\
Low shade agrof 3 & 57.1 & 169,577 & $9,834,508$ \\
Low shade agrof 4 & 42.5 & 168,735 & $9,832,676$ \\
\hline
\end{tabular}

74006) by two people independently at 12 random positions within each plot above cacao tree canopy.

We used trap nests to assess relative densities of the above ground-nesting wasp $R$. haemorrhoidale. Trap nests consisted of PVC tubes (length $28 \mathrm{~cm}$, diameter 14 $\mathrm{cm})$ with internodes of the grass Saccharum spontaneum (Poaceae) of varying diameter (3-25 mm) and a length of $20 \mathrm{~cm}$ inserted (Tscharntke et al. 1998). Sixteen trap nests per site were installed from October 2004 until September 2005 in different heights from understorey to canopy. The trap nests were checked every month and sticky glue was applied to the edge of the PVC tube to deter ants from colonizing the trap nests. We collected all internodes, which were occupied by Hymenopterans readily identifiable by the type of caps closing the internode opening, and incubated all larvae and pupae including parasitoids in glass tubes until they hatched, for later species identification. Due to simplification of terminology, we equated the term density with number of brood cells, as done in former studies (Gathmann et al. 1994; Steffan-Dewenter 2003). The eumenid predatory wasp $R$. haemorrhoidale was identified by Dr. J. Gusenleitner from Linz, Austria. Voucher specimens are kept at the Bogor Agricultural University (IPB) in Indonesia.

Pupal body size is a widely used fitness-related trait for insects and can be used as a surrogate for food supply (e.g. Harvey et al. 2000; Östman 2005). We could not estimate the density of the prey (see: 'Study organisms') of the predator R. haemorrhoidale in the field, because the prey larvae fed in higher strata of the cacao tree canopies. We measured body length (henceforth: body size) of $R$. haemorrhoidale pupae with a vernier calliper in November 04 and June 05 for a seasonal comparison. Larvae of this species completely ate prey larvae in the brood cells, therefore we used pupae size as a surrogate for food resource availability. Assessment of sex ratio and sex determination was also done in November 04 and June 05 . We compared months throughout the year and effects of season when we compared November (wet season) with June (dry season). We recorded individuals of $R$. haemorrhoidale that were not parasitized, but died as egg, larva or pupa for unknown reasons, such as infections by entomopathogenic organisms (viral, bacterial, nematode or fungal infection), for every month. In order to lessen the mortality associated with breeding in glass tubes, we attempted to create close to optimal conditions for $R$. haemorrhoidale. The climatic conditions air temperature, humidity, solar 
radiation and precipitation were measured at a climate station in the centre of the research area to assess seasonal fluctuations.

\section{Study organisms}

We used the tropical cavity nesting eumenid wasp species $R$. haemorrhoidale (F.) (Eumenidae, Hymenoptera) for this study. $R$. haemorrhoidale is a solitary, predatory wasp, building nests with several brood cells. It was the most abundant species out of 23 predacious wasps. $R$. haemorrhoidale can be considered as an effective pest predator, as we found that each brood cell was provided with approximately seven larvae of the pest organism A. caliginosalis. The generation time from egg to adult never went below one month, which was the sampling frequency for the trap nests and therefore we can exclude that wasps developed, hatched and flew out unrecognized from trap nests. Parasitoids of $R$. haemorrhoidale comprise a spectrum from cleptoparasitoids (Chrysididae and Rhippiphoridae), ectoparasitoids (Leucospidae) and endoparasitoids (Ichneumonidae) to hyperparasitoids (Trigonalyidae).

\section{Statistical analysis}

We used main effects ANOVA to test for differences in density and sex ratio per plot between months (density) and seasons (sex ratio), respectively, and habitat. Density was defined as number of brood cells occupied. Density and sex ratio were used as dependent variables and habitat type and month/ season as categorical predictors. Sex ratio was calculated as number of male individuals per plot divided by number of female individuals. We show density values in primary forest plots only in Fig. 4 and did not include the individuals from this habitat for further statistics, because $R$. haemorrhoidale proved to be a species depending on less dense forested habitats, such as agroforestry systems. Only 24 individuals of $R$. haemorrhoidale occurred in all four primary forest plots throughout the year.

We used Spearman rank correlation to test whether wasp density per plot and month and canopy cover per plot were correlated.

We used a correlation matrix to test whether the climatic factors temperature, humidity, solar radiation and precipitation were correlated. In another correlation matrix we tested whether monthly density values of $R$. haemorrhoidale were correlated with climatic factors. We correlated density with climatic values not just from the same month, but also from the previous three months as density response of $R$. haemorrhoidale to climatic changes might be temporally delayed when climate influences prey density and thereby density of $R$. haemorrhoidale. Due to four replications of the model with climate values from different months, we used a Bonferroni corrected $\alpha$ of 0.0125 .

To test whether habitat or season influenced food resource availability, we used main effects ANOVA with body size of the pupae as dependent variable and habitat and season as categorical predictors. We did the analysis for both sexes separately, as females were significantly larger than males.

We conducted a general linear model (GLM) to identify the factors that influence parasitism of $R$. haemorrhoidale and non-parasitism mortality rate. The two models included parasitism and non-parasitism mortality rate respectively as response variables, habitat and month as categorical predictors and R. haemorrhoidale (host) density as continuous variables. Parasitism rate was calculated as number of infested host individuals divided by number of parasitized individuals per plot. Non-parasitism mortality rate was calculated as total number of individuals per plot divided by number of individuals that died for reasons others than parasitism. To test the effect of habitat and month on species richness of parasitoids of $R$. haemorrhoidale we conducted a main effects ANOVA with number of species as response variable and month and habitat as categorical predictors.

Square root transformation was done to assure for homogeneity of variance if necessary. We used type-I (sequential) sum of squares for each model. We give arithmetic mean \pm standard error in the text.

\section{Results}

In total we reared 11,090 individuals from 50 species in the trap nests. Twenty three of these species were specialized predatory wasps with $R$. haemorrhoidale (7,403 individuals), a larvae hunting eumenid wasp, the most abundant species, comprising $67 \%$ of all individuals and therefore used as the organism of interest. Canopy cover varied between plots, with primary forest plots having the densest canopy (95.6 $\pm 0.8 \%$ ), followed by low intensity plots $(72.5 \pm$ 
$4.5 \%)$, medium intensity plots $(61.4 \pm 6.3 \%)$ and high intensity plots $(58.1 \pm 8.4 \%)$ (Table 1$)$. We therefore refer to the different agroforestry plots as high, medium and low shade plots.

\section{Season and habitat quality}

Density of $R$. haemorrhoidale was strongly influenced by season with rising number of brood cells from October until January $\left(r^{2}=0.484, F_{11,107}=\right.$ 11.8, $P<0.001$ ) (Fig. 1) and increased number of brood cells with increased land-use intensity $\left(r^{2}=\right.$ 0.066, $F_{2,107}=8.8, P<0.001$ ) (Fig. 2). High shade agroforestry plots had significantly fewer individuals

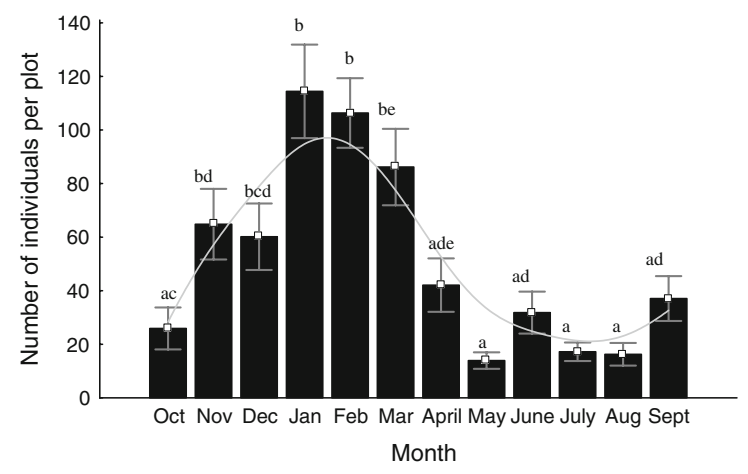

Fig. 1 Numbers of individuals of $R$. haemorrhoidale per month and plot from October 2004 until September 2005. Mean \pm standard error are shown. Significant differences $(P<$ $0.05)$ are indicated by different letters. The grey fitting line represents distance weighted least squares

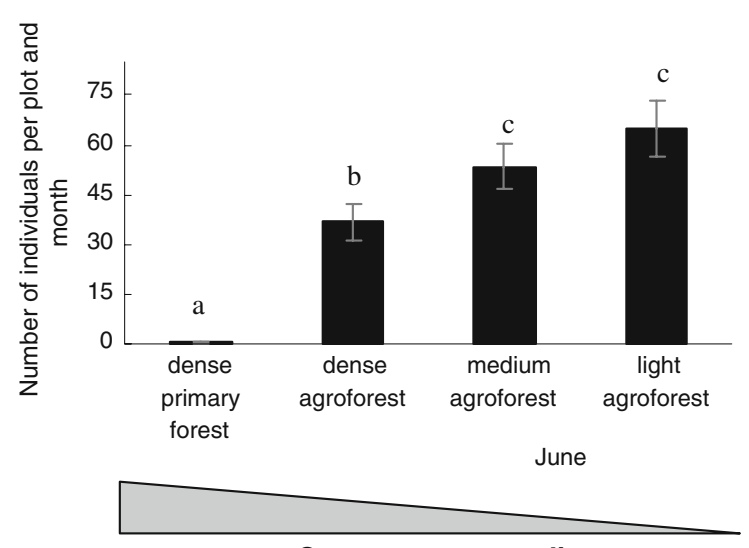

Canopy cover gradient

Fig. 2 Numbers of individuals of $R$. haemorrrhoidale per month and replicate for 1 year and for four habitat. Mean \pm standard error are shown. Different letters indicate significant differences between habitat types per month and plot $(36.7 \pm 5.67, n=48)$ compared to medium $(53.3 \pm 6.78)$ and low shade agroforestry plots $(64.8 \pm 8.5)$. There was no interaction between season and land-use intensity $\left(r^{2}=0.051, F_{22,107}=\right.$ $0.63, P=0.897)$. Canopy cover and wasp density per plot and month were negatively correlated $(n=16, R$ $=-0.54, P=0.033)$. Neither habitat $\left(r^{2}=0.09, F_{2,19}\right.$ $=1, P=0.384)$ nor season $\left(r^{2}=0.06, F_{1,19}=1.31, P\right.$ $=0.267$ ) influenced sex ratio of the wasp.

\section{Climatic variables}

Climatic variables were not intercorrelated and no climatic variable was correlated with density of $R$. haemorrhoidale from the same month or the previous month. In a correlation matrix with climatic factors from the previous month, density was also not correlated with climate. Solar radiation did not influence $R$. haemorrhoidale ( $n=12, R=0.6, P=$ $0.039, \alpha=0.0125$ ).

\section{Food resources}

Seasonal differences in pupal size were similar in either sex. Females and males were larger in the dry season (June) compared to wet season (November) (females June: $1.83 \pm 0.014 \mathrm{~cm}$; November: $1.69 \pm$ $0.0123 \mathrm{~cm} ; r^{2}=0.13, F_{1,387}=58.06, P<0.0001$; males June: $1.48 \pm 0.012 \mathrm{~cm}$; November: $1.34 \pm$ $\left.0.013 \mathrm{~cm} ; r^{2}=0.15 ; F_{1,374}=64.54 ; P<0.001\right)$ (Fig. 3). Habitat did not influence pupal size in either sex (females: $r^{2}<0.01 ; F_{2,387}=1.54 ; P=0.215$; males: $\left.r^{2}<0.01 ; F_{2,374}=1.64 ; P=0.195\right)$.

Parasitism and non-parasitism mortality

We found 579 individuals of parasitoids from $R$. haemorrhoidale belonging to seven species (see Methods, Study organism). These were $3 \pm 0.38$ parasitoids and $39 \pm 3.5$ individuals of the host $R$. haemorrhoidale on average from each plot per month. For statistical analyses we pooled all parasitoid species, as all species caused mortality of $R$. haemorrhoidale. Parasitism rate of $R$. haemorrhoidale differed between months $\left(r^{2}=0.24, F_{11,109}=3.146, P=\right.$ 0.001 ), with November having a higher parasitism rate compared to October, August and September (Fig. 4), but did not show a difference between habitats $\left(r^{2}=0.01, F_{2,109}=0.8, P=0.449\right)$ or host 
density throughout the year $\left(r^{2}<0,01, F_{1,109}=0.57\right.$, $P=0.45)$. Parasitoids of $R$. haemorrhoidale showed higher species richness in the rainy season $\left(r^{2}=0.62\right.$, $\left.F_{11,22}=3.3, P=0.008\right)$ with significantly more species in February (3.66 \pm 0.33$)$ compared to October $(1 \pm 0)$, whereas habitat had no influence on species richness $\left(r^{2}<0.01, F_{2,22}=0.04, P=0.96\right)$.

The rate of non-parasitism mortality was not influenced by any predictor variable (habitat: $r^{2}=$ $0.05, F_{2,109}=3.06, P=0.051$; month: $r^{2}=0.13$,

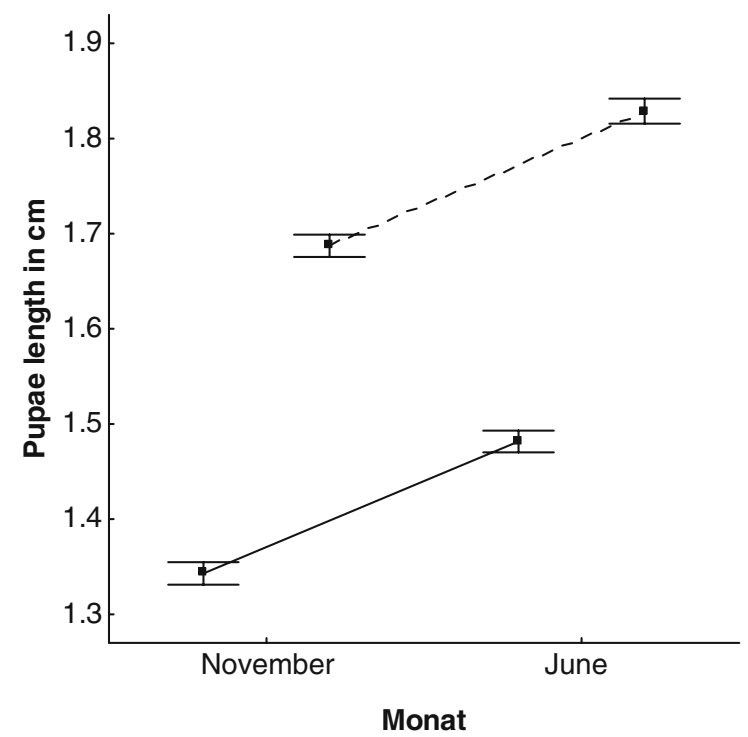

Fig. 3 Wasp pupae lengths of $R$. haemorrrhoidale for 2 months, with dashed line representing female individuals and solid line representing male individuals. Mean \pm standard error are shown
$F_{11,109}=1.56, P=0.122$; density: $r^{2}=0.05, F_{1,109}=$ $0.06, P=0.8)$.

\section{Discussion}

Density of $R$. haemorrhoidale was strongly influenced by month and land-use intensity, but not directly related to seasonal temperature variation. We found a strong seasonality of $R$. haemorrrhoidale with higher monthly densities in the wet season. We could not find a significant direct synchronization between wasp density and climate, even though increased flight and foraging activity, has been shown to depend on temperature (Strohm and Linsenmair 1998; Ribeiro et al. 2006). Furthermore, wasp density was influenced by land-use intensity, with densely shaded agroforest plots having fewer individuals compared to medium and light shaded agroforests and almost none in highly shaded primary forests. This might be explained by more favourable abiotic conditions or by higher food availability. In less shaded plots solar radiation penetrates through the canopy and reaches the ground, thus increasing temperature and reducing humidity (Grimmond et al. 2000). Vespidae are known to profit from solar radiation and temperature (Ishay and Lior 1990; Elisei et al. 2005), in particular in terms of nest building and foraging activity. Thus the effect of habitat type on wasp densities might be due to the influence of canopy cover on climatic conditions in the plots as wasp density and canopy cover were negatively correlated. Further, the choice of nesting
Fig. 4 Parasitism rate of $R$. haemorrhoidale by seven species of parasitoids per month and plot from October 2004 until September 2005. Mean \pm standard error are shown. Significant differences $(P<$ 0.05 ) are indicated by different letters

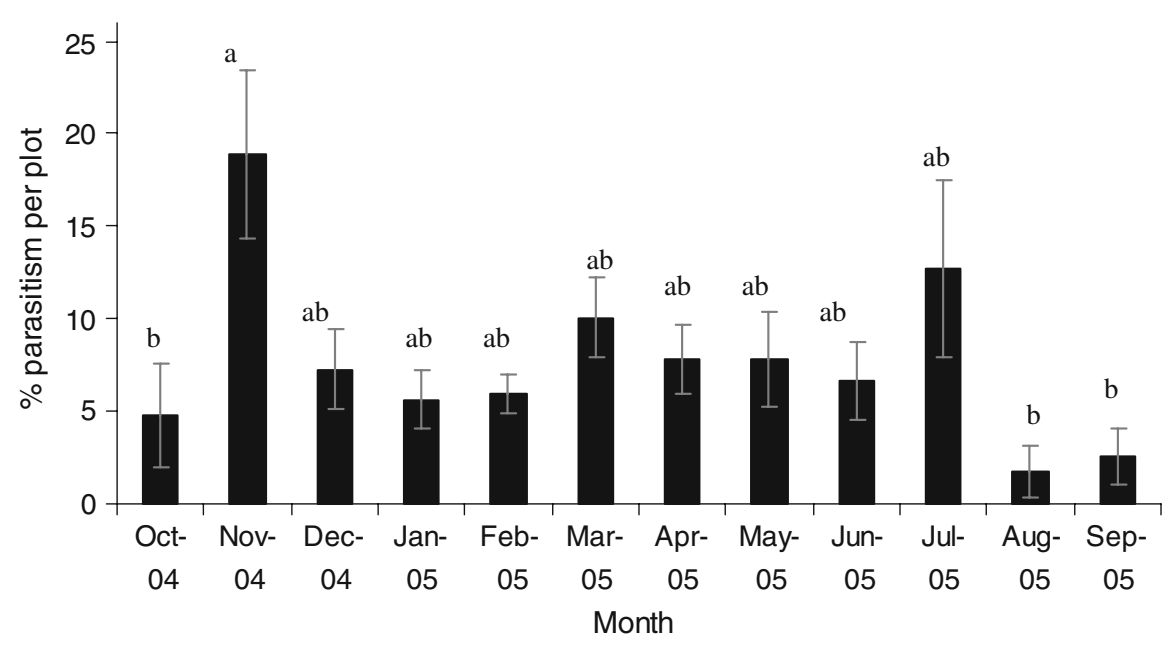


sites might have been also influenced by other habitat characteristics, such as natural nesting site availability and prey availability.

Body size of females and males of $R$. haemorrhoidale was higher in June, indicating better larval food supply in the beginning of the dry season, rather than at the end of the dry season. Reduced food supply in November could be due to intraspecific competition for food resources, as wasp density increased in November. In seasons with high wasp density, intraspecific competition could reduce individual food supply and result in smaller individuals, as abundant wasp species with a narrow prey spectrum, such as $R$. haemorrrhoidale, can effectively reduce prey densities in the field (Harris 1996; Schenk and Bacher 2002). Temporal variation in body size was synchronized among sites, showing the superposing effect of seasonal change on food supply independent of habitat type (Östman 2005). Klein et al. (2004) showed that $R$. haemorrhoidale adjusted foraging trip duration to habitat quality and its density was not correlated with foraging time, indicating that food resource availability may not directly affect $R$. haemorrrhoidale density.

Sex ratio was similar between seasons, thus independent of prey availability. Sex ratio has been discussed to depend on environmental factors, whereby unfavourable conditions lead to more males (Frank and Swingland 1988), as found for the European beewolf (Philanthus triangulum F., Sphecidae) (Strohm and Linsenmair 1997). Male individuals represent the 'cheaper sex' with higher relative fitness under poor conditions, such as food shortage. Also non-parasitism mortality was not influenced by food supply, since it was not higher in the season with smaller individuals. However, some authors discuss a positive relation between fitness (e.g. development time, mating success, survivorship) and body size of insects, such as braconids, odonates and carabids (Harvey et al. 2000; Sokolovska et al. 2000; Östman 2005).

Parasitism rate in November was considerably higher compared to August, September and October. This peak appeared to be a response to increasing host densities at the beginning of the wet season, but parasitism rate throughout the year is not correlated with host density. Species richness of parasitoids of $R$. haemorrhoidale was also higher in the middle of the rainy season compared to the end of the dry season. For example, the Chrysis sp. smaragdula group occurred only in the rainy season.
In conclusion, food resource availability and climate may contribute to seasonal changes in life history traits in temperate zones as well as in the tropics (Kemp 2001; Nicolas et al. 2005; Polidori et al. 2007). However, it is often difficult to determine the proximate reasons for seasonality of tropical species. We showed that habitat choice for nesting was related to canopy cover and season, in that density of $R$. haemorrhoidale was higher in sunny agroforestry and in the wet season, which may be related to prey availability.

We show that agroforestry systems in agricultural landscapes, can maintain high densities of a potentially important cacao pest predator. The moth larvaehunting $R$. haemorrhoidale was almost absent in the primary forest and its density increased with land-use intensity Our results suggest that by adding nesting resources for this specific pest predator biological pest control could be significantly improved in intensively managed agroforestry systems where density and diversity of other natural enemies tends to be low (Klein et al. 2002). However, we could not measure effects on cacao defoliation and other potential predators of pest insects might get lost during agroforestry intensification.

Acknowledgements We thank Sarina Pearce, Riccardo Bommarco and Örjan Östman for valuable suggestions and ideas on the manuscript and the following experts for the identification of species: Gian Luca Agnoli, Bologna (Chrysididae), J. Gusenleitner, Linz (Vespidae), Christian Schulze, Wien (Pyralidae) and Jan Batelka, Prague (Ripiphoridae). We thank the Deutsche Forschungsgemeinschaft (DFG) for the financial support of the Collaborative Research Centre STORMA (SFB 552), LIPI for the research permit and supporting field work. We are grateful to the STORMA coordination offices in Göttingen, Palu and Bogor for organisational support, field and lab assistants in Toro and Palu and the plot owners for the patience to let us use their land.

\section{References}

Bischoff I (2003) Population dynamics of the solitary digger bee Andrena vaga (Panzer Hymenoptera, Andrenidae) studied using mark-recapture and nest counts. Popul Ecol 5:197-204. doi:10.1007/s10144-003-0156-6

Boggs CL, Freeman KD (2005) Larval food limitation in butterflies: effects on adult resource allocation and fitness. Oecologia 144:53-361. doi:10.1007/s00442-005-0076-6

Bommarco R (1999) Feeding, reproduction and community impact of a predatory carabid in two agricultural habitats. Oikos 87:89-96. doi:10.2307/3546999 
Brown P, Shine R (2006) Why do most tropical animals reproduce seasonally? Testing hypotheses on an Australian snake. Ecology 87:33-143

Cleary DFR, van Ginkel W (2004) Effects of host species and size on brood size and larval mortality of the parasitoid, Ageniaspis fuscicollis (Dalman) (Hymenoptera, Encyrtidae). Environ Entomol 33:528-534

Clough Y, Kruess A, Tscharntke T (2007) Organic versus conventional arable farming systems: functional grouping helps understand staphylinid response. Agric Ecosyst Environ 118:285-290. doi:10.1016/j.agee.2006.05.028

Dietsch TV, Perfecto I, Greenberg R (2007) Avian foraging behavior in two different types of coffee agroecosystem in Chiapas, Mexico. Biotropica 39:232-240. doi:10.1111/ j.1744-7429.2006.00248.x

Elisei T, Junior CR, Guimaraes DL, Prezoto F (2005) Foraging activity and nesting of swarm-founding wasp Synoeca cyanea (Hymenoptera: Vespidae, Epiponini). Sociobiology 46:317-327

Forsman A, Lindell LE (1997) Responses of a predator to variation in prey abundance: survival and emigration of adders in relation to vole density. Can J Zool-Rev Can Zool 75:1099-1108. doi:10.1139/z97-132

Frank SA, Swingland IR (1988) Sex ratio under conditional sex expression. J Theor Biol 135:415-418. doi:10.1016/ S0022-5193(88)80256-X

Furlong MJ, Pell JK (2001) Horizontal transmission of entomopathogenic fungi by the diamondback moth. Biol Control 22:288-299. doi:10.1006/bcon.2001.0981

Gathmann A, Greiler HJ, Tscharntke T (1994) Trap-nesting bees and wasps colonizing set-aside fields-succession and body-size, management by cutting and sowing. Oecologia 98:8-14. doi:10.1007/BF00326084

Grimmond CSB, Robeson SM, Schoof JT (2000) Spatial variability of micro-climatic conditions within a mid-latitude deciduous forest. Clim Res 15:137-149. doi:10.3354/ cr015137

Harris RJ (1996) Frequency of overwintered Vespula germanica (Hymenoptera: Vespidae) colonies in scrubland-pasture habitat and their impact on prey. NZ J Zool 23:11-17

Harris DB, MacDonald DW (2007) Population ecology of the endemic rodent Nesoryzomys swarthi in the tropical desert of the Galapagos Islands. J Mammal 88:208-219. doi: 10.1644/05-MAMM-A-370R4.1

Harvey JA, Kadash K, Strand MR (2000) Differences in larval feeding behaviour correlate with altered developmental strategies in two parasitic wasps: implications for the sizefitness hypothesis. Oikos 88:621-629. doi:10.1034/j.16000706.2000.880319.x

Ishay JS, Lior SME (1990) Digging activity by the oriental hornet (Vespa orientalis, Hymenoptera, Vespinae) is correlated with solar-radiation. J Ethol 8:61-68. doi: 10.1007/BF02350275

Kemp DJ (2001) Reproductive seasonality in the tropical butterfly Hypolimnas bolina (Lepidoptera: Nymphalidae) in northern Australia. J Trop Ecol 17:483-494. doi: $10.1017 / \mathrm{S} 0266467401001365$

King BH (1996) Fitness effects of sex ratio response to host quality and size in the parasitoid wasp Spalangia cameroni. Behav Ecol 7:35-42. doi:10.1093/beheco/7.1.35
Klein AM, Steffan-Dewenter I, Tscharntke T (2002) Predatorprey ratios on cocoa along a land-use gradient in Indonesia. Biodivers Conserv 11:683-693. doi:10.1023/A: 1015548426672

Klein AM, Steffan-Dewenter I, Tscharntke T (2004) Foraging trip duration and density of megachilid bees, eumenid wasps and pompilid wasps in tropical agroforestry systems. J Anim Ecol 73:517-525. doi:10.1111/j.0021-8790. 2004.00826.x

Lambert TD, Malcolm JR, Zimmerman BL (2006) Amazonian small mammal abundances in relation to habitat structure and resource abundance. J Mammal 87:766-776. doi: 10.1644/05-MAMM-A-261R1.1

Liu HP, Bauer LS, Miller DL, Zhao TH, Gao RT, Song LW et al (2007) Seasonal abundance of Agrilus planipennis (Coleoptera: Buprestidae) and its natural enemies Oobius agrili (Hymenoptera: Encyrtidae) and Tetrastichus planipennisi (Hymenoptera: Eulophidae) in China. Biol Control 42:61-71. doi:10.1016/j.biocontrol.2007.03.011

Millennium Ecosystem Assessment (2005) Current state \& trends assessment, Chap 21. Island Press, Washington DC

Morton A, Del Pino FG (2007) Susceptibility of shore fly Scatella stagnalis to five entomopathogenic nematode strains in bioassays. Biocontrol 52:533-545. doi:10.1007/ s10526-006-9047-z

Nicolas V, Barriere P, Colyn M (2005) Seasonal variation in population and community structure of shrews in a tropical forest of Gabon. J Trop Ecol 21:161-169. doi: $10.1017 / \mathrm{S} 0266467404002123$

Norrdahl K, Korpimaki E (2002) Seasonal changes in the numerical responses of predators to cyclic vole populations. Ecography 25:428-438. doi:10.1034/j.1600-0587. 2002.250405.x

Östman Ö (2005) Asynchronous temporal variation among sites in condition of two carabid species. Ecol Entomol 30:63-69. doi:10.1111/j.0307-6946.2005.00661.x

Perfecto I, Vandermeer JH, Bautista GL, Nunez GI, Greenberg R, Bichier P et al (2004) Greater predation in shaded coffee farms: the role of resident neotropical birds. Ecology 85:2677-2681. doi:10.1890/03-3145

Philpott SM, Perfecto I, Vandermeer J (2007) Effects of management intensity and season on arboreal ant diversity and abundance in coffee agroecosystems. Biodivers Conserv 15:139-155. doi:10.1007/s10531-004-4247-2

Polidori C, Boesi R, Pesarini C, Papadia C, Bevacqua S, Federici $\mathrm{M}$ et al (2007) Temporal relationship between the prey spectrum and population structure of the weevilhunting wasp Cerceris arenaria (Hymenoptera: Crabronidae). Zool Stud 46:83-91

Ribeiro C, Guimaraes DL, Elisei T, Prezoto F (2006) Foraging activity rhythm of the neotropical swarm-founding wasp Protopolybia exigua (Hymenoptera, Vespidae, Epiponini) in different seasons of the year. Sociobiology 47:115-123

Richards LA, Coley PD (2007) Seasonal and habitat differences affect the impact of food and predation on herbivores: a comparison between gaps and understory of a tropical forest. Oikos 116:31-40. doi:10.1111/j.2006. 0030-1299.15043.x

Richards LA, Windsor DM (2007) Seasonal variation of arthropod abundance in gaps and the understorey of a 
lowland moist forest in Panama. J Trop Ecol 23:169-176. doi:10.1017/S0266467406003907

Salamolard M, Butet A, Leroux A, Bretagnolle V (2000) Responses of an avian predator to variations in prey density at a temperate latitude. Ecology 81:2428-2441

Schenk D, Bacher S (2002) Functional response of a generalist insect predator to one of its prey species in the field. $\mathrm{J}$ Anim Ecol 71:524-531. doi:10.1046/j.1365-2656.2002. 00620.x

Schmidt MH, Roschewitz I, Thies C, Tscharntke T (2005) Differential effects of landscape and management on diversity and density of ground-dwelling farmland spiders. J Appl Ecol 42:281-287. doi:10.1111/j.1365-2664. 2005.01014.x

Sokolovska N, Rowe L, Johansson F (2000) Fitness and body size in mature odonates. Ecol Entomol 25:239-248. doi: 10.1046/j.1365-2311.2000.00251.x

Steffan-Dewenter I (2003) Importance of habitat area and landscape context for species richness of bees and wasps in fragmented orchard meadows. Conserv Biol 17:10361044. doi:10.1046/j.1523-1739.2003.01575.x

Steffan-Dewenter I, Schiele S (2008) Do resources or natural enemies drive bee population dynamics in fragmented landscapes? Ecology 89:1375-1387

Steffan-Dewenter I, Kessler M, Barkmann J, Bos M, Buchori D, Erasmi S et al (2007) Tradeoffs between income, biodiversity, and ecosystem functioning during tropical rainforest conversion and agroforestry intensification. Proc Natl Acad Sci USA 104:4973-4978. doi:10.1073/ pnas.0608409104

Strohm E, Linsenmair KE (1997) Low resource availability causes extremely male biased investment ratios in the European beewolf, Philanthus triangulum F (Hymenoptera, Sphecidae). Proc R Soc Lond B Biol Sci 264:423429. doi:10.1098/rspb.1997.0060

Strohm E, Linsenmair KE (1998) Temperature dependence of provisioning behaviour and investment allocation in the European beewolf Philanthus triangulum F. Ecol Entomol 23:330-339. doi:10.1046/j.1365-2311.1998.00129.x

Teder T, Tammaru T (2003) Short-term indirect interactions between two moth (Lepidoptera: Noctuidae) species mediated by shared parasitoids: the benefit of being scarce. Eur J Entomol 100:323-328

Tscharntke T (1992) Coexistence, tritrophic interactions and density dependence in a species-rich parasitoid community. J Anim Ecol 61:59-67. doi:10.2307/5509

Tscharntke T, Gathmann A, Steffan-Dewenter I (1998) Bioindication using trap nesting bees and wasps and their natural enemies: community structure and interactions. J Appl Ecol 35:708-719

Zhou G, Baumgartner J, Overholt WA (2001) Impact assessment of an exotic parasitoid on stemborer (Lepidoptera) population dynamics in Kenya. Ecol Appl 11:1554-1562. doi: 10.1890/1051-0761(2001)011[1554:IAOAEP]2.0.CO;2 